\title{
Metabolic effects of milk protein intake strongly depend on pre-existing metabolic and exercise status
}

\author{
Bodo C Melnik ${ }^{*}$, Gerd Schmitz ${ }^{2}$, Swen Malte John ${ }^{1}$, Pedro Carrera-Bastos ${ }^{3}$, Staffan Lindeberg ${ }^{3}$ and Loren Cordain ${ }^{4}$
}

\begin{abstract}
Milk protein intake has recently been suggested to improve metabolic health. This Perspective provides evidence that metabolic effects of milk protein intake have to be regarded in the context of the individual's pre-existing metabolic and exercise status. Milk proteins provide abundant branched-chain amino acids (BCAAs) and glutamine. Plasma BCAAs and glutamine are increased in obesity and insulin resistance, but decrease after gastric bypass surgery resulting in weight loss and improved insulin sensitivity. Milk protein consumption results in postprandial hyperinsulinemia in obese subjects, increases body weight of overweight adolescents and may thus deteriorate pre-existing metabolic disturbances of obese, insulin resistant individuals.
\end{abstract}

Keywords: Adipogenesis, Body weight, Branched-chain amino acids, Glutaminolysis, Insulin resistance, Milk proteins, microRNA, mTORC1, Obesity, Prostate cancer

\section{Introduction}

Recently McGregor and Poppitt suggested milk protein intake for the improvement of metabolic health [1]. However, the authors missed important insights into branched-chain amino acid (BCAA) metabolism under conditions of obesity and insulin resistance. They emphasized beneficial effects of milk protein ingestion for skeletal muscle but ignored adverse effects of BCAAs on adipose tissue and long-term $\beta$-cell homeostasis. Obviously, milk's physiological function promoting neonatal growth is not restricted to the musculoskeletal system. It is the intention of this Perspective article to demonstrate that the evaluation of metabolic effects of milk protein consumption has to consider the nutritional and endocrine status and the level of physical activity of the milk protein consumer.

\section{Milk proteins increase BCAA influx}

Plasma BCAAs (leucine, isoleucine, valine) and glutamine/glutamate are increased in obesity, insulin resistance and type 2-diabetes (T2D) [2-9]. An extra daily intake of

\footnotetext{
* Correspondence: melnik@t-online.de

'Department of Dermatology, Environmental Medicine and Health Theory, University of Osnabrück, Osnabrück, Germany

Full list of author information is available at the end of the article
}

$53 \mathrm{~g}$ milk protein but not $53 \mathrm{~g}$ meat increased serum insulin and insulin resistance in 8-year-old boys [10]. Impaired BCAA catabolism of adipocytes is a crucial metabolic deviation of obesity [11,12] (Figure 1A). As BCAA plasma levels in obesity are already elevated an additional BCAA influx may further deteriorate the preexisting metabolic imbalance. In fact, the marked decrease in BCAA plasma levels resulting from gastric bypass surgery is associated with weight loss and improved insulin sensitivity $[13,14]$. Palaeolithic, physically active hunter-gatherers consumed structural proteins like fish and meat. In contrast, modern Neolithic humans have "mutated" into physically inactive individuals, who particularly consume signalling proteins from milk providing abundant "fast dietary proteins" leading to high plasma BCAA and glutamine levels [15]. Palaeolithic dairy-free diets exhibit lower insulin levels with improved insulin sensitivity protecting against the development of diseases of civilization [16-19].

\section{Mechanical stimuli increase mTORC1-mediated muscle protein synthesis \\ According to our opinion it may be hazardous to pro- mote milk protein consumption especially in obese indi- viduals with sedentary lifestyles and/or insulin resistance.}



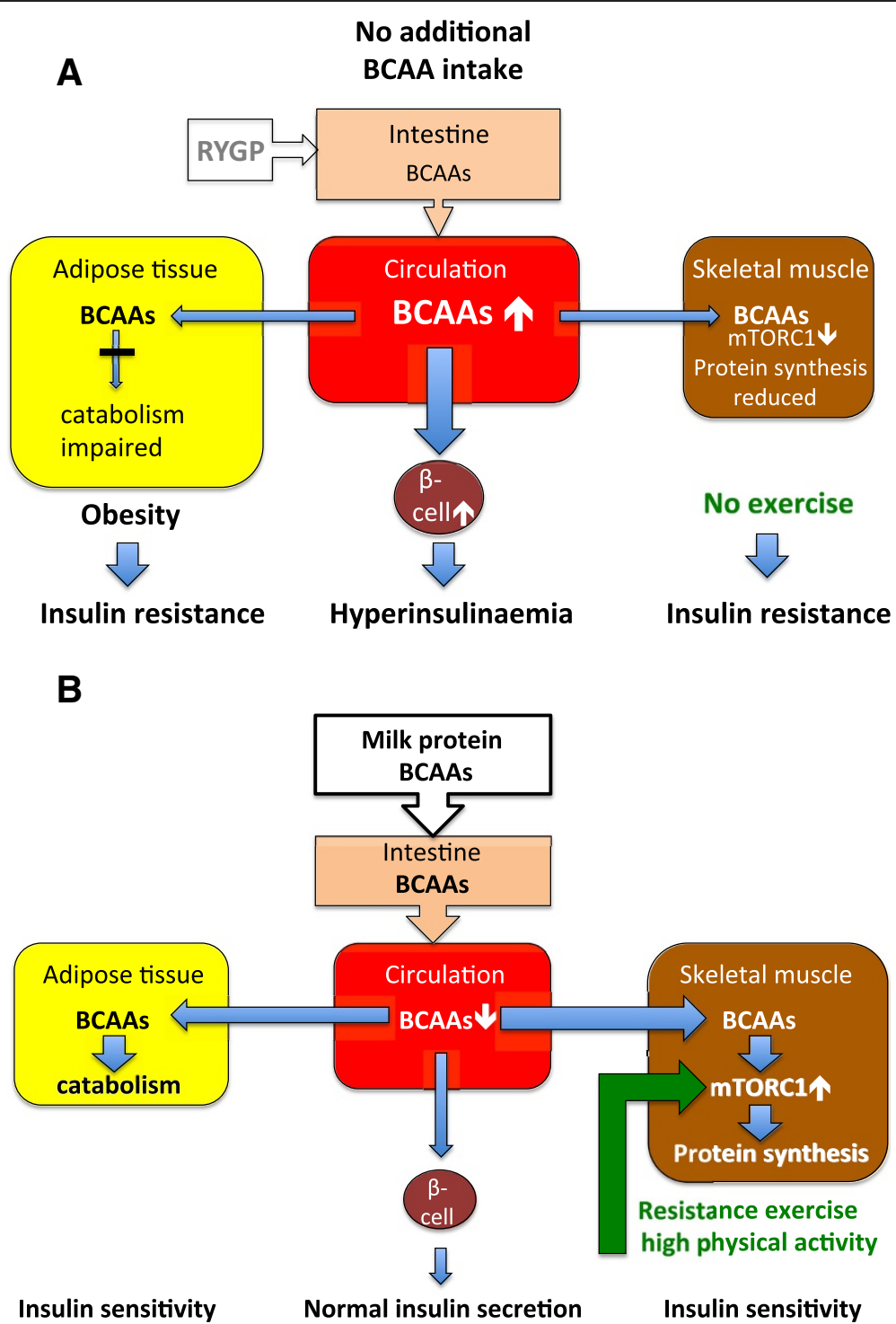

Figure 1 BCAA metabolism in obese, sedentary subjects versus healthy, physically active individuals. A. Deviated BCAA metabolism in obese, sedentary individuals. B. BCAA metabolism in healthy physically active individuals. BCAA = branched-chain amino acids (leucine, isoleucine, valine). RYGP = Roux-en-Y gastric bypass surgery.

Although BCAAs are required for mTORC1-dependent muscle protein synthesis $[20,21]$, BCAA intake alone is not sufficient to significantly increase muscle mass. Mechanical stimuli, which activate mTORC1 in myocytes, are of critical importance to cause significant skeletal muscle hypertrophy [22,23] (Figure 1B). Intriguingly, eccentric muscle contractions increase mTORC1 activation by phosphorylation of tuberous sclerosis complex-2 (TSC2) associated with the translocation of TSC2 away from the lysosome [24]. According to a recent model, mTORC1 activation occurs at the lysosome and is mediated through an amino acid-sensing cascade involving RAG GTPases, Ragulator and vacuolar $\mathrm{H}^{+}$-ATPase $[25,26]$. Whey proteins contain highest amounts of BCAAs [27-29]. Whey protein intake after resistance exercise substantially increased mTORC1 activity in skeletal muscle of healthy young men [30]. Thus, weight loss and muscle gain in conjunction with increased milk protein intake may only be successful in combination with enhanced physical activity (Figure 1B) [31]. In contrast, additional intake of BCAAs in sedentary obese subjects may further deteriorate metabolic control resulting in hyperinsulinemia, insulin resistance and T2D (Figure 1A).

\section{Milk protein consumption and postprandial} hyperinsulinemia in obesity

Of all animal proteins, whey proteins contain the highest amount of leucine (14\% of total amino acids) [27]. Whey 
proteins are "fast proteins" [15], that are hydrolysed within minutes in the intestine and immediately increase BCAA levels in the systemic circulation thus functioning like an intravenous administration of amino acids [29,32]. In healthy lean individuals oral administration of leucine induces postprandial hyperinsulinemia especially in combination with increased glucose intake [33,34]. In obese subjects, oral administration of leucine induces exaggerated and prolonged postprandial hyperinsulinemia without significant changes of blood glucose levels [34-36]. In children, daily intake of $53 \mathrm{~g}$ milk protein, but not of $53 \mathrm{~g}$ meat induced hyperinsulinemia and insulin resistance under fasting conditions [10]. In overweight adolescents daily intake of $35 \mathrm{~g}$ whey protein or casein significantly increased fasting plasma insulin levels [37]. Thus, there is substantial evidence that increased milk protein consumption in obese individuals persistently over-stimulates insulin secretion, which in the long term may promote early onset of $\beta$-cell apoptosis. Milk-stimulated islet cell hyperplasia and $\beta$-cell hyperresponsiveness are obviously physiological metabolic effects that promote anabolism and postnatal growth. However, experimental evidence in $\beta$-cell $\mathrm{TSC}^{-/-}$ deficient mice indicates that persistently increased mTORC1-mediated $\beta$-cell stimulation from the beginning of postnatal life induced hyperinsulinemia and enhanced $\beta$-cell proliferation during adolescence but early onset of $\beta$-cell apoptosis with decreased insulin secretion in adulthood [38].

\section{Milk consumption, obesity and risk of type 2-diabetes}

Milk ingestion is a novel human behaviour introduced by the Neolithic revolution, industrially maximized by widespread refrigeration technology [39]. The NHANES [40] and the Growing-Up Today Study [41] observed increased BMI in children and adolescents in association with increased milk consumption. Weight gain associated with increased milk intake has also been observed in healthy adults [42]. Supplementation of milk protein (either $35 \mathrm{~g}$ whey protein, skim milk protein, or casein) to overweight adolescents further increased body weight [37]. Accordingly, chronic leucine supplementation in rats on a high-fat diet further increased body weight [43]. Leucine plays a pivotal role for mTORC1 activation [44-46] including adipocytes $[47,48]$. Leucyl-tRNA synthetase is another recently identified key mediator for BCAA-induced mTORC1 activation [49]. mTORC1 is a central regulator of adipogenesis linking BCAA abundance to mTORC1-driven obesity [50]. BMI is a critical determinant for the induction of pubertal growth. Notably, the NHANES study found a correlation between milk consumption in children with increased BMI [40] and early age of menarche [51], a risk factor for the development of obesity, T2D and metabolic syndrome
[52-56]. Milk proteins are enriched in glutamine [57], the precursor of the glutaminolysis pathway, which plays a crucial role for insulin secretion [58]. Remarkably, glutamate dehydrogenase is allosterically activated by leucine $[59,60]$. Thus, leucine- and glutamine overload by high milk protein consumption, may permanently overstimulate insulin secretion and mTORC1 signalling. In fact, elevated plasma levels of BCAAs and glutamate are positively correlated with increased BMI and insulin resistance $[4,7]$.

\section{Increased BCAA availability and insulin resistance}

There is compelling evidence that amino acid availability regulates S6 kinase and multiple translation factors [61]. BCAAs by increasing mTORC1-S6K1 signalling act as positive signals for maintenance of protein stores, while inhibiting other actions of insulin at multiple levels [62]. In amino acid-infused humans, over-activation of mTORC1S6K1 pathway increased inhibitory insulin receptor substrate (IRS)-1 phosphorylation at Ser312, Ser636/639 and Ser1101 resulting in insulin resistance of skeletal muscle [63-65]. Thus, there is substantial evidence that inappropriate activation of mTORC1-S6K1 signalling by amino acids induces insulin resistance, the fundamental metabolic deviation leading to T2D [9,63-66]. Whey proteins in contrast to meat proteins provide fast hydrolysable BCAAs comparable to a BCAA infusion promoting insulin secretion and insulin resistance, major intrinsic mechanisms of milk signalling $[10,67]$.

\section{Milk protein consumption and risk of prostate cancer}

Nutrition plays an important role in mTORC1-driven cancer development $[26,46,68,69]$. mTORC1 steers prostate cancer (PCa) initiation and metastasis [69]. Accumulating evidence links $\mathrm{PCa}$ initiation and progression to increased milk protein consumption and milk-mediated activation of mTORC1 [70]. The European Prospective Investigation into Cancer and Nutrition confirmed that high intake of dairy protein is associated with an increased risk of $\mathrm{PCa}$ [71]. A $35 \mathrm{~g} /$ day increase in dairy protein intake was associated with an increased risk of $\mathrm{PCa}$ of 32\% [71]. Furthermore, increased PCa-specific mortality has recently been associated with increased whole milk intake [72]. In contrast to meat, milk and milk protein fractions contain substantial amounts of exosomal microRNAs, predominantly microRNA-21 [73-75], that is an oncogenic and adipogenic microRNA [76,77]. Remarkably, addition of commercial milk to PCa cell cultures increased the proliferation of cancer cells by $30 \%$ [78]. Furthermore, commercial milk contains substantial amounts of the let-7 microRNA family [75]. Notably, it has recently been demonstrated that over-expression of let-7 induced insulin resistance $[79,80]$. 


\section{Conclusions}

There is no evidence that milk proteins per se improve metabolic health. In contrast, increased consumption of milk proteins may further impair BCAA metabolism of obese, insulin resistant, sedentary individuals. It is now clear that not calorie restriction but BCAA restriction extends lifespan in Drosophila melanogaster [81,82]. Reduction of BCAA intake with reduced mTORC1 activation explains the metabolic benefits of dietary restriction $[83,84]$. Persistent leucine-mediated hyperinsulinemia in obesity induced by persistent milk protein consumption may promote an earlier onset of $\beta$-cell apoptosis. Epidemiological evidence underlines the association between increased milk intake and higher BMI, increased milk intake and early onset of menarche, and the association of increased BMI as well as early menarche and increased risk of T2D. Thus, we recommend a more careful and restricted use of milk proteins, especially in the setting of pre-existent obesity, insulin resistance as well as sedentary life style.

\section{Abbreviations}

AA: Amino acids; BCAA: Branched-chain amino acid; GDH: Glutamate dehydrogenase; BMI: Body mass index; microRNA: micro-ribonucleic acid; mTORC1: mechanistic (mammalian) target of rapamycin complex 1; PCa: Prostate cancer; RYGS: Roux-en-Y-gastric bypass surgery; T2D: Type 2 diabetes.

\section{Competing interests}

BCM, GS, SMJ, PCB, SL and LC have declared no competing interests.

\section{Authors' contributions}

BCM wrote the manuscript. BCM, GS, SMJ, PCB, SL and LC searched and critically reviewed the literature. All authors read and approved the final manuscript.

\section{Author details}

'Department of Dermatology, Environmental Medicine and Health Theory, University of Osnabrück, Osnabrück, Germany. ${ }^{2}$ Institute of Clinical Chemistry and Laboratory Medicine, University Clinics of Regensburg, Regensburg, Germany. ${ }^{3}$ Center for Primary Health Care Research, Lund University, Lund, Sweden. ${ }^{4}$ Department of Health and Exercise Science, Colorado State University, Fort Collins CO 80523, USA.

Received: 16 July 2013 Accepted: 28 September 2013 Published: 2 October 2013

\section{References}

1. McGregor RA, Poppitt SD: Milk protein for improved metabolic health: a review of the evidence. Nutr Metab (Lond) 2013, 10(1):46.

2. Adibi SA: Influence of dietary deprivations on plasma concentrations of free amino acids of man. J Appl Physiol 1968, 25:52-57.

3. Felig M, Cahill GF Jr: Plasma amino acid levels and insulin secretion in obesity. N Engl J Med 1969, 281:811-816.

4. Newgard CB, An J, Bain JR, Muehlbauer MJ, Stevens RD, Lien LF, et al: A branched-chain amino acid-related metabolic signature that differentiates obese and lean humans and contributes to insulin resistance. Cell Metab 2009, 9:311-326.

5. Melnik BC, John SM, Schmitz G: Overstimulation of insulin/IGF-1 signaling by western diet may promote diseases of civilization: lessons learnt from Laron syndrome. Nutr Metab (Lond) 2011, 8:4.

6. Melnik BC: Leucine signalling in the pathogenesis of type 2 diabetes and obesity. World J Diabetes 2012, 3(3):38-53.

7. McCormack SE, Shaham O, McCarthy MA, Deik AA, Wang TJ, Gerszten RE, et al: Circulating branched-chain amino acid concentrations are associated with obesity and future insulin resistance in children and adolescents. Pediatr Obes 2013, 8(1):52-61.

8. Morris C, O'Grada C, Ryan M, Roche HM, Gibney MJ, Gibney ER, et al: The relationship between $\mathrm{BMI}$ and metabolomics profiles: a focus on amino acids. Proceed Nutr Soc 2012, 71:634-638.

9. Lu J, Xie G, Jia W, Jia W: Insulin resistance and the metabolism of branched-chain amino acids. Front Med 2013, 7(1):53-59.

10. Hoppe C, Molgaard C, Vaag A, Barkholt V, Michaelsen KF: High intakes of milk, but not meat, increase s-insulin and insulin resistance in 8-year-old boys. Eur J Clin Nutr 2005, 59(3):393-398.

11. Lackey DE, Lynch CJ, Olson KC, Mostaedi R, Ali M, Smith WH, et al: Regulation of adipose branched-chain amino acid catabolism enzyme expression and cross-adipose amino acid flux in human obesity. Am J Physiol Endocrinol Metab 2013, 304(11):E1175-E1187.

12. She P, Van Horn C, Reid T, Hutson SM, Cooney RN, Lynch CJ: Obesityrelated elevations in plasma leucine are associated with alterations in enzymes involved in branched-chain amino acid metabolism. Am J Physiol Endocrinol Metab 2007, 293:E1552-E1563.

13. Mutch DM, Fuhrmann JC, Rein D, Wiemer JC, Bouillot JL, Poitou C Metabolite profiling identifies candidate markers reflecting the clinical adaptations associated with Roux-en-Y gastric bypass surgery. PLOS ONE 2009, 4(11):e7905.

14. Laferrere B, Reilly D, Arias S, Swerdlow N, Gorroochurn P, Bawa B, et al: Differential metabolic impact of gastric bypass surgery versus dietary intervention in obese subjects despite identical weight loss. Sci Tran/Med 2011, 3:80-82

15. Frühbeck G: Slow and fast dietary proteins. Nature 1998, 391:843-845.

16. Lindeberg S, Eliasson M, Lindahl B, Ahrén B: Low serum insulin in traditional Pacific islanders - the Kitava study. Metabolism 1999, 48:1216-1219.

17. Eaton SB, Konner M: Paleolithic nutrition. A consideration of its nature and current implications. N Engl J Med 1985, 313:283-289.

18. Carrera-Bastos P, Fontes-Villabla M, O'Keefe JH, Lindeberg S, Cordain L: The western diet and lifestyle and diseases of civilization. Res Rep Clin Cardiol 2011, 2:15-35.

19. Lindeberg S: Paleolithic diets as model for prevention and treatment of Western disease. Am J Hum Biol 2012, 24:110-115.

20. Suryawan A, Davis TA: Regulation of protein synthesis by amino acids in muscle of neonates. Front Biosci 2012, 16:1445-1460.

21. Yoshizawa F, Mochizuki S, Sugahara K: Differential dose response of mTOR signaling to oral administration of leucine in skeletal muscle and liver in rats. Biosci Biotech Biochem 2013, 77(4):839-842.

22. Hornberger TA, Sukhija KB, Chien S: Regulation of mTOR by mechanically induced signaling events in skeletal muscle. Cell Cycle 2006, 5(13): 1391-1396.

23. Hornberger TA: Mechanotransduction and the regulation of mTORC1 signaling in skeletal muscle. Int J Biochem Cell Biol 2011, 43:1267-1276.

24. Jacobs BL, You JS, Frey JW, Goodman CA, Gundermann DM, Hornberger TA: Eccentric contractions increase the phosphorylation of tuberous sclerosis complex-2 (TSC2) and alter the targeting of TSC2 and the mechanistic target of rapamycin to the lysosome. J Physio/ 2013, 591:4611-4620.

25. Jewell JL, Russell RC, Guan KL: Amino acid signalling upstream of mTOR. Nat Rev Mol Cell Biol 2013, 14:133-139.

26. Kim SG, Buel GR, Blenis J: Nutrient regulation of the mTOR complex 1 signaling pathway. Mol Cells 2013, 35:463-473.

27. Millward DJ, Layman DK, Tomé D, Schaafsma G: Protein quality assessment: impact of expanding understanding of protein and amino acid needs for optimal health. Am J Clin Nutr 2008, 87:1576S-1581S.

28. Hall WL, Millward DJ, Long SJ, Morgan LM: Casein and whey exert different effects on plasma amino acid profiles, gastrointestinal hormone secretion and appetite. Br J Nutr 2003, 89(2):239-248.

29. Boirie $Y$, Dangin M, Gachon P, Vasson MP, Maubois JL, Beaufrère B: Slow and fast dietary proteins differently modulate postprandial protein accretion. Proc Natl Acad Sci U S A 1997, 94(26):14930-14935.

30. Farnfield MM, Carey KA, Gran P, Trenerry MK, Cameron-Smith D: Whey protein ingestion activates $\mathrm{mTOR}$-dependent signalling after resistance exercise in young men: a double-blinded randomized controlled trial. Nutrients 2009, 1:263-275.

31. Josse AR, Atkinson SA, Tarnopolsky MA, Phillips SM: Increased consumption of dairy foods and protein during diet- and exercise- induced weight loss promotes fat mass loss and lean mass in overweight and obese premenopausal women. J Nutr 2011, 141:1626-1634. 
32. Nilsson M, Holst JJ, Björck IE: Metabolic effects of amino acid mixtures and whey protein in healthy subjects: studies using glucose-equivalent drinks. Am J Clin Nutr 2007, 85:996-1004.

33. DiGeorge AM, Auerbach VH, Mabry CC: Elevated serum insulin associated with leucine-induced hypoglycaemia. Nature 1960, 188:1036-1037.

34. Loridan L, Sadeghi-Nejad A, Senior B: Hypersecretion of insulin after the administration of L-leucine to obese children. J Pediatr 1971, 78:53-58.

35. Kalogeropoulou D, LaFave L, Schweim K, Gannon MC, Nuttall FQ: Leucine, when ingested with glucose, synergistically stimulates insulin secretion and lowers blood glucose. Metabolism 2008, 57:1747-1752.

36. Johnson S, Karam JH, Levin SR, Grodsky GM, Forsham PH: Hyperinsulin response to oral leucine in obesity and acromegaly. J Clin Endocrinol Metab 1973, 37:431-435

37. Arnberg K, Mølgaard C, Michaelsen KF, Jensen SM, Trolle E, Larnkjær A: Skim milk, whey, and casein increase body weight and whey and casein increase the plasma C-peptide concentration in overweight adolescents. J Nutr 2012, 142:2083-2090.

38. Shigeyama Y, Kobayashi T, Kido Y, Hashimoto N, Asahara SI, Matsuda T, et al: Biphasic response of pancreatic $\beta$-cell mass to ablation of tuberous sclerosis complex 2 in mice. Mol Cell Biol 2008, 28:2971-2979.

39. Wiley AS: Cow milk consumption, insulin-like growth factor-I, and human biology: a life history approach. Am J Hum Biol 2012, 24:130-138.

40. Wiley AS: Dairy and milk consumption and child growth: is BMI involved? An analysis of NHANES 1999-2004. Am J Hum Biol 2010, 22:517-525.

41. Berkey CS, Rockett HH, Willett WC, Colditz GA: Milk, dairy fat, dietary calcium, and weight gain. Arch Pediatr Adolesc Med 2005, 159:543-550.

42. Barr SI, MCCarron DA, Heany RP, Dawson-Highes B, Berga SL, Stern JS, et al: Effects of increased consumption of fluid milk on energy and nutrient intake, body weight, and cardiovascular risk factors in healthy older adults. J Am Diet Assoc 2000, 100:810-817.

43. Li X, Wang X, Liu R, Ma Y, Guo H, Hao L, et al: Chronic leucine supplementation increases body weight and insulin sensitivity in rats on high-fat diet likely by promoting insulin signalling in insulin-target tissues. Mol Nutr Food Res 2013, 57(6):1067-1079.

44. Dodd KM, Tee AR: Leucine and mTORC1: a complex relationship. Am J Physiol Endocrinol Metab 2012, 302:E1329-E1342.

45. Foster KG, Fingar DC: Mammalian target of rapamycin (mTOR): conducting the cellular signaling symphony. J Biol Chem 2010, 285 (19):14071-14077.

46. Zoncu R, Efeyan A, Sabatini DM: mTOR: from growth signal integration to cancer, diabetes and ageing. Nat Rev Mol Cell Biol 2011, 12:21-35.

47. Fox HL, Pham PT, Kimball SR, Jefferson LS, Lynch CJ: Amino acid effects on translational repressor 4E-BP1 are mediated primarily by L-leucine in isolated adipocytes. Am J Physiol 1998, 275:C1232-C1238.

48. Pham PT, Heydrick SJ, Fox HL, Kimball SR, Jefferson LS Jr, Lynch CJ: Assessment of cell-signaling pathways in the regulation of mammalian target of rapamycin (mTOR) by amino acids in rat adipocytes. J Cell Biochem 2000, 79:427-441.

49. Han JM, Jeong SJ, Park MC, Kim G, Kwon NH, Kim HK, et al: Leucyl-tRNA synthetase is an intracellular leucine sensor for the mTORC1-signaling pathway. Cell 2012, 149:410-424.

50. Yoon MS, Zhang C, Sun Y, Schoenherr CJ, Chen J: Mechanistic target of rapamycin (mTOR) controls homeostasis of adipogenesis. J Lipid Res 2013, 54(8):2166-2173.

51. Wiley AS: Milk intake and total dairy consumption: associations with early menarche in NHANES 1999-2004. PLOS ONE 2011, 6:e14685.

52. Chen L, Zhang C, Yeung E, Ye A, Mumford SL, Wactawski-Wende J, et al: Age at menarche and metabolic markers for type 2 diabetes in premenopausal women: the BioCycle Study. J Clin Endocrinol Metab 2011, 96:E1007-E1012.

53. Pierce MB, Kuh D, Hardy R: The role of BMI across the life course in the relationship between age at menarche and diabetes, in a British Birth Cohort. Diabet Med 2012, 29:600-603.

54. Conway BN, Shu XO, Zhang X, Xiang YB, Cai H, Li H, et al: Age at menarche, the leg length to sitting height ratio, and risk of diabetes in middle-aged and elderly Chinese men and women. PLOS ONE 2012, 7:e30625.

55. Dreyfus JG, Lutsey PL, Huxley R, Pankow JS, Selvin E, Fernández-Rhodes L, et al: Age at menarche and risk of type 2 diabetes among African-American and white women in the Atherosclerosis Risk in Communities (ARIC) study. Diabetologia 2012, 55:2371-2380.
56. Stöckl D, Meisinger C, Peters A, Thorand B, Huth C, Heier M, et al: Age at menarche and its association with the metabolic syndrome and its components: results from the KORA F4 study. PLOS ONE 2011, 6:e26076.

57. Sindayikengera S, Xia WS: Nutritional evaluation of casein and whey proteins and their hydrolysates from Protamex. J Zhejiang Univ SCIENCE B 2006, 7(2):90-98.

58. Carobbio S, Ishihara H, Fernandez-Pascual S, Bartley C, Martin-Del-Rio R, Maechler P: Insulin secretion profiles are modified by overexpression of glutamate dehydrogenase in pancreatic islets. Diabetologica 2004, 47:266-276

59. Yielding KL, Tomkins GM: An effect of L-leucine and other essential amino acids on the structure and activity of glutamic dehydrogenase. Proc Natl Acad Sci USA 1961, 47:983-989.

60. Li M, Li C, Allen A, Stanley CA, Smith TJ: The structure and allosteric regulation of mammalian glutamate dehydrogenase. Arch Biochem Biophys 2012, 519(2):69-80.

61. Wang X, Campbell LE, Miller CM, Proud CG: Amino acid availability regulates p70 S6 kinase and multiple translation factors. Biochem J 1998 334:261-267.

62. Patti ME, Brambilla E, Luzi L, Landaker EJ, Kahn CR: Bidirectional modulation of insulin action by amino acids. J Clin Invest 1998, 101:1519-1529.

63. Krebs M, Krssak M, Bernroider E, Anderwald C, Brehm A, Meyerspeer M, et al: Mechanism of amino acid-induced skeletal muscle insulin resistance in humans. Diabetes 2002, 51:599-605

64. Tremblay F, Krebs M, Dombrowski L, Brehm A, Bernroider E, Roth E, et al: Overactivation of S6 kinase 1 as a cause of human insulin resistance during increased amino acid availability. Diabetes 2005, 54:2674-2684.

65. Tremblay F, Brulé S, Um SH, Masuda K, Roden M, Sun XJ, et al: Identification of Ser-1101 as a target of S6K1 in nutrient- and obesity-induced insulin resistance. Proc Natl Acad Sci U S A 2007, 104:14056-14061.

66. Shah OJ, Wang Z, Hunter T: Inappropriate activation of the TSC/Rheb/ mTOR/S6K cassette induces IRS1/2 depletion, insulin resistance, and cell survival deficiencies. Curr Biol 2004, 14:1650-1656.

67. Melnik BC, John SM, Schmitz G: Milk is not just food but most likely a genetic transfection system activating mTORC1 signalling for postnatal growth. Nutr J 2013, 12:103.

68. Pópulo $H$, Lopes JM, Soares P: The mTOR signalling pathway in human cancer. Int J Mol Sci 2012, 13:1886-1918.

69. Hsieh AC, Liu Y, Edlind MP, Ingolia NT, Janes MR, Sher A, et al: The translational landscape of mTOR signaling steers cancer initiation and metastasis. Nature 2012, 485(7396):55-61.

70. Melnik BC, John SM, Carrera-Bastos P, Cordain L: The impact of cow's milk-mediated mTORC1-signalling in the initiation and progression of prostate cancer. Nutr Metab (Lond) 2012, 9(1):74.

71. Allen NE, Key TJ, Appleby PN, Travis RC, Roddam AW, Tjonneland A, et al: Animal foods, protein, calcium and prostate cancer risk: the European Prospective Investigation into Cancer and Nutrition. Br J Cancer 2008, 98:1574-1581.

72. Song Y, Chavarro JE, Cao Y, Qiu W, Mucci L, Sesso HD, et al: Whole milk intake is associated with prostate cancer-specific mortality among U.S. male physicians. J Nutr 2013, 143(2):189-196.

73. Chen X, Gao C, Li H, Huang L, Sun Q, Dong Y, et al: Identification and characterization of microRNAs in raw milk during different periods of lactation, commercial fluid, and powdered milk products. Cell Res 2010, 20:1128-1137.

74. Izumi H, Kosaka N, Shimizu T, Sekine K, Ochiya T, Takase M: Bovine milk contains microRNA and messenger RNA that are stable under degradative conditions. J Dairy Sci 2012, 95:4831-4841.

75. Izumi H, Kosala N, Shimizu T, Sekine K, Ochiya T, Takase M: Purification of RNA from milk whey. Methods Mol Biol 2013, 1024:191-201.

76. Becker Buscaglia LE, Li Y: Apoptosis and the target genes of miR-21. Chin J Cancer 2011, 30:371-380

77. Kim YJ, Hwang SJ, Bae YC, Jung JS: Mir-21 regulates adipogenic differentiation through the modulation of TGF- $\beta$ signalling in mesenchymal stem cells derived from human adipose tissue. Stem Cells 2009, 27:3093-3102.

78. Tate PL, Bibb R, Larcom LL: Milk stimulates growth of prostate cancer cells in culture. Nutr Cancer 2011, 63(8):1361-1366.

79. Zhu H, Shyh-Chang N, Segrè AV, Shinoda G, Shah SP, Einhorn WS, et al: The Lin28/let-7 axis regulates glucose metabolism. Cell 2011, 147:81-94. 
80. Frost RJ, Olson EN: Control of glucose homeostasis and insulin sensitivity by the Let-7 family of microRNAs. Proc Natl Acad Sci U S A 2011, 52:21075-21080

81. Grandison RC, Piper MDW, Partridge L: Amino acid imbalance explains extension of lifespan by dietary restriction in Drosophila. Nature 2009, 462(7276):1061-1064.

82. Tartar M: The plate half-full: Status of research on the mechanisms of dietary restriction in Drosophila melanogaster. Exp Gerontol 2011, 46(5):363-368

83. Gallinetti J, Harputlugil E, Mitchell JR: Amino acid sensing in dietaryrestriction-mediated longevity: roles of signal-transducing kinases GCN2 and TOR. Biochem J 2013, 449(1):1-10.

84. Kapahi P, Chen D, Rogers AN, Katewa SD, Li PW, Thomas EL, et al: With TOR less is more. A key role for the conserved nutrient sensing TOR pathway in aging. Cell Metab 2010, 11(6):453-465.

doi:10.1186/1743-7075-10-60

Cite this article as: Melnik et al:: Metabolic effects of milk protein intake strongly depend on pre-existing metabolic and exercise status. Nutrition \& Metabolism 2013 10:60.

\section{Submit your next manuscript to BioMed Central and take full advantage of:}

- Convenient online submission

- Thorough peer review

- No space constraints or color figure charges

- Immediate publication on acceptance

- Inclusion in PubMed, CAS, Scopus and Google Scholar

- Research which is freely available for redistribution 